\title{
STUDI TENTANG PERAN MUSYAWARAH GURU \\ MATA PELAJARAN AKUNTANSI DALAM MENINGKATKAN \\ PROFESIONALITAS GURU AKUNTANSI SMK DI DIY
}

Oleh :

Ani Widayati ${ }^{1}$

\begin{abstract}
Abstrak
Penelitian ini bertujuan untuk (1) memperoleh gambaran program kerja MGMP Akuntansi Kelompok Bisnis dan Manajemen DIY, (2) memperoleh gambaran peran MGMP Akuntansi Kelompok Bisnis dan Manajemen DIY dalam meningkatkan profesionalitas guru Akuntansi SMK DIY, (3) memperoleh gambaran kendala yang dihadapi MGMP Akuntansi Kelompok Bisnis dan Manajemen DIY dalam menjalankan program kerjanya, (4) memperoleh gambaran usaha yang telah dilakukan MGMP Akuntansi Kelompok Bisnis dan Manajemen DIY untuk mengatasi kendala yang dihadapi.

Subjek penelitian adalah pengurus dan anggota MGMP Akuntansi se Kabupaten Sleman sebanyak 38 orang. Istrumen utama penelitian ini adalah angket (kuisioner). Namun untuk melengkapi dan juga triangulasi dalam rangka validasi data, juga disusun dan digunakan instrumen lain berupa pedoman wawancara. Data dianalisis secara deskriptif untuk menggambarkan peran MGMP Akuntansi Kelompok Bisnis dan Manajemen dalam meningkatkan profesionalitas guru Akuntansi. Data disajikan dalam bentuk tabel dengan persentase, kemudian dideskripsikan untuk diambil kriteria dan kesimpulan.

Hasil penelitian menunjukkan bahwa (1) Program kerja MGMP disusun setiap tahun dan diadakan evaluasi pada akhir tahun. Program kerja yang terlaksana adalah peningkatan kemampuan guru, pembahasan kurikulum dan pembahasan mengenai LKS, (2) Peran MGMP dalam meningkatkan profesionalitas guru tergolong tinggi dilihat dari indikator peran dalam reformasi pembelajaran tergolong tinggi $(73,7 \%)$, sebagai mediator peningkatan kompetensi guru tergolong tinggi (57,9\%), sebagai supporting agency dalam inovasi manajemen kelas dan sekolah tergolong tinggi yaitu sebesar 57,9\%, peran MGMP sebagai collaborator sekolah tergolong tinggi (57,9\%), sebagai evaluator sekolah tergolong tinggi $(68,4 \%)$, serta dalam supervisi akademik dan klinis tergolong tinggi yaitu sebesar $73,7 \%$, (3) Kendala yang dihadapi oleh MGMP adalah mengenai pendanaan yang belum optimal dan pengaturan waktu untuk pelaksanaan program kerja yang relatif sulit, (4) Usaha yang dilakukan oleh MGMP untuk mengatasi kendala adalah dengan mengadakan iuran bagi guru-guru agar program kerja dapat terlaksana dan menggunakan waktu libur sekolah untuk melaksanakan agenda program kerja.

Kata kunci: peran MGMP Akuntansi,profesionalitas guru, Daerah Istimewa Yogykarta
\end{abstract}

\footnotetext{
${ }^{1}$ Staf Pengajar Jurusan P. Akuntansi Fakultas Ekononi Universitas Negeri Yogyakarta
} 


\section{A. Pendahuluan}

Pendidikan nasional berfungsi mengembangkan kemampuan dan membentuk watak serta peradaban bangsa yang bermartabat dalam rangka mencerdaskan kehidupan bangsa, bertujuan untuk berkembangnya potensi peserta didik agar menjadi manusia yang beriman dan bertakwa kepada Tuhan Yang Maha Esa, berakhlak mulia, sehat, berilmu, cakap, kreatif, mandiri, dan menjadi warga negara yang demokratis serta bertanggung jawab. Pada kenyataannya pendidikan merupakan suatu usaha yang tidak mudah melainkan penuh dengan tantangan. Pendidikan selalu berubah dari waktu ke waktu sesuai dengan perkembangan masyarakat. Pendidikan harus selalu menyesuaikan dengan perkembangan yang terjadi di masyarakat mengingat sumber daya di segala bidang menggantungkan pada keberhasilan pendidikan. Sumber daya yang berkualitas sebagai outcome dari pendidikan sangat diperlukan untuk membangun masyarakat agar dapat bersaing secara internasional. Untuk dapat menghasilkan sumberdaya yang berkualitas maka kulaitas pendidikan menjadi sorotan utama.

Faktor-faktor yang menentukan baik buruknya pendidikan mesti diperhatikan. Faktor kurikulum ditinjau agar dapat menyesuiakan dengan kebutuhan masyarakat. Apakah kurikulum telah memenuhi kebutuhan? Hal ini menjadi pemikiran bersama mengingat cepatnya masyarakat berkembang, sementara tinjauan kurikulum dilakukan setiap empat tahun sekali. Faktor penunjang pendidikan perlu juga mendapat perhatian. Sarana prasarana yang menunjang pendidikan belum dapat dirasakan oleh semua sekolah. Masih banyak sekolah yang mengalami kekurangan sarana prasarana untuk memperlancar pendidikan. Faktor biaya pendidikan yang dirasa berat bagi sebagaian rakyat Indonesia utuk menyelenggarakan pendidikan yang baik juga merupakan permasalahan yang perlu memproleh perhatian. Faktor yang lain yang sangat penting untuk diperhatikan adalah guru. Bagaimana profesionalitas guru dalam menyelenggarakan pendidikan perlu dikaji. Kompetensi guru untuk mendidik generasi muda perlu dikaji dan ditingkatkan mengingat salah satu penyebab kegagalan pendidikan kemungkinan adalah faktor guru sebagai pemegang peran utama dalam penyelenggaraan pendidikan.

Guru menurut Undang Undang No. 14 tahun 2005 merupakan pendidik profesional dengan tugas utama mendidik, mengajar, membimbing, mengarahkan, melatih, menilai, dan mengevaluasi peserta didik pada pendidikan anak usia dini jalur formal, pendidikan dasar, dan pendidikan menengah. Guru dituntut untuk mempunyai profesionalitas dalam menjalankan tugasnya. Guru yang profesional diharapkan dapat menciptakan kualitas lulusan yang dapat bersaing secara global. Profesionalitas guru dibuktikan dengan dimilikinya sertifikat pendidik. Profesionalitas guru dimaksudkan untuk meningkatkan martabat dan peran guru sebagai agen pembelajaran yang berfungsi untuk meningkatkan kualitas pendidikan nasional. Profesionalitas ini diakui ketika guru telah memiliki kualifikasi akademik, kompetensi, dan sertifikasi pendidik yang dipersyaratkan. 
Berbagai kegiatan diselenggarakan agar guru dapat memperbaiki kinerjanya sehingga dapat dikatakan sebagai guru yang profesional. Kegiatan imiah seperti seminar, pendidikan dan pelatihan dilaksanakan untuk meningkatkan profesionalitas guru. Sesama guru mata pelajaran tertentu membentuk forum kegiatan yang dapat digunakan untuk mewadahi kepentingan guru dalam menigkatkan profesionalitasnya.

Salah satu wadah kegiatan guru untuk meningkatkan profesionalitasnya adalah Musyawarah Guru Mata Pelajaran (MGMP). Untuk mata pelajaran Akuntansi dibentuk MGMP Akuntansi. Sawali (2009) menyatakan bahwa keberadaan Musyawarah Guru Mata Pelajaran (MGMP) selama ini terkesan "mandul" dan belum memiliki peran yang bermakna dalam melakukan perubahan substansial dan mendasar dalam upaya meningkatkan mutu pendidikan. MGMP sebagai wadah komunikasi guru belum diberdayakan secara optimal. Guru belum sepenuhnya berperan aktif sehingga komunikasi dapat dibina untuk memecahkan berbagai permasalahan yang dihadapinya untuk meningkatkan profesionalitasnya.

Keberadaan MGMP Akuntansi DIY secara organisatoris telah ada dan berfungsi. Namun kadang-kadang sistem pelaksanaan programnya kurang efektif sehingga tujuan yang diharapkan tidak tercapai secara optimal. Selama ini MGMP Akuntansi DIY melakukan kegiatan diskusi untuk menyamakan persepsi mengenai perubahan kurikulum, membahas berbagai permasalahan yang muncul baik spesifik maupun umum yang berkaitan dengan pembelajaran Akuntansi. Bagi sebagian guru kegiatan MGMP sangat membantu akan tetapi sebagian guru yang lain menganggap bahwa kegiatan MGMP merupakan kegiatan klasik, hanya berkumpul untuk bertemu teman seprofesi tanpa membawa hasil bukan dilandasi motivasi yang tinggi akan pentingnya wawasan dan pengetahuan untuk meningkatkan kompetensi agar menjadi guru yang profesional.

MGMP Akuntansi sebagai salah satu upaya untuk meningkatkan profesionalitas guru hendaknya dapat dijadikan sebagai wadah untuk komunikasi bagi guru-guru mata pelajaran Akuntansi. Komunikasi dimaksudkan untuk melihat kelebihan dan kekurangan yang dihadapi guru mengenai permasalahan kurikulum dan pembelajaran sehingga mereka dapat bertukar pikiran, pengalaman maupun informasi mengenai bagaimana memahami dan memaknai kurikulum dan pelaksanaan proses pembelajaran yang efektif dan efisien untuk meningkatkan kualitas lulusan seperti Berdasarkan kajian tersebut, dirumuskan permasalahan sebagai berikut:

1. Bagaimanakan program kerja MGMP Akuntansi Kelompok Bisnis dan Manajemen DIY?

2. Bagaimana peran MGMP Akuntansi Kelompok Bisnis dan Manajemen DIY dalam meningkatkan profesionalitas guru Akuntansi SMK di DIY?

3. Apa kendala yang dihadapi MGMP Akuntansi Kelompok Bisnis dan Manajemen DIY dalam menjalankan program kerjanya? 
4. Sejauh mana usaha yang telah dilakukan MGMP Akuntansi Kelompok Bisnis dan Manajemen DIY untuk mengatasi kendala yang dihadapi?

Musyawarah Guru Mata Pelajaran (MGMP) merupakan suatu wadah asosiasi atau perkumpulan bagi guru mata pelajaran yang berada dalam satu sanggar/ kabupaten/kota yang berfungsi sebagai sarana untuk saling berkomunikasi, belajar dan bertukar pikiran dan pengalaman dalam rangka meningkatkan kinerja guru sebagai praktisi/perilaku perubahan reorientasi pembelajaran di kelas (Depdiknas, 4004:1). Arief Mangkoesaputro menjelaskan bahwa MGMP merupakan suatu forum atau wadah profesional guru mata pelajaran yang berada pada suatu wilayah baik kabupaten, kota, maupun gugus sekolah. Forum ini mempunyai anggota yang meliputi guru mata pelajaran pada SMP, SMA maupun SMK baik Negeri dan Swasta, baik yang berstatus PNS maupun Swasta, guru tetap maupun tidak tetap. MGMP merupakan organisasi nonstruktural yang bersifat mandiri, berasaskan kekeluargaan, dan tidak mempunyai hubungan hierarkis dengan lembaga lain. Meski demikian MGMP merupakan organisasi yang berfungsi membantu guru oleh guru untuk semua sekolah. (Diakses dari Homepage Pendidikan Network tanggal 17 Pebruari 2010).

MGMP berdiri bukan tanpa tujuan. Tujuan secara umum diselenggarakannya MGMP adalah untuk mengembangkan kreativitasdan inovasi dalam meningkatkan profesionalisme guru. Sedangkan tujuan secara khusus adalah untuk:

1. Memperluas wawasan dan pengetahuan guru mata pelajaran dalam upaya mewujudkan pembelajaran yang efektif dan efisien

2. Mengembangkan kultur kelas yang kondusif sebagai tempat proses pembelajaran yang menyenangkan, mengasyikan dan mencerdaskan siswa

3. Membangun kerjasama dengan masyarakat sebagai mitra guru dalam melaksanakan proses pembelajaran

(Depdiknas, 2004:2)

Tidak jauh berbeda, Arief Mangkoesaputro mengungkapkan bahwa keberadaan MGMP bertujuan untuk:

1. memotivasi guru guna meningkatkan kemampuan dan keterampilan dalam merencanakan, melaksanakan, dan membuat evaluasi program pembelajaran dalam rangka meningkatkan keyakinan diri sebagai guru professional.

2. menyatakan kemampuan dan kemahiran guru dalam melaksanakan pembelajaran sehingga dapat menunjang usaha peningkatan dan pemerataan mutu pendidikan.

3. mendiskusikan permasalahan yang dihadapi dan dialami oleh guru dalam melaksanakan tugas sehari-hari dan mencari solusi alternatif pemecahannya sesuai dengan karakteristik mata pelajaran masing-masing, guru, kondisi sekolah, dan lingkungannya. 
4. untuk membantu guru memperoleh informasi teknis edukatif yang berkaitan dengan kegiatan ilmu pengetahuan dan teknologi, kegiatan kurikulum, metodologi, dan sistem pengujian yang sesuai dengan mata pelajaran yang bersangkutan.

5. saling berbagi informasi dan pengalaman dari hasil lokakarya, simposium, seminar, diklat, classroom action research, referensi, dan lain-lain kegiatan profesional yang dibahas bersama-sama

6. mampu menjabarkan dan merumuskan agenda reformasi sekolah (school reform), khususnya focus classroom reform, sehingga berproses pada reorientasi pembelajaran yang efektif

MGMP, selain mempunyai tujuan seperti dijelaskan di atas juga dituntut mempunyai peran untuk:

1. Mengakomodasi aspirasi dari, oleh dan untuk anggota

2. Mengakomodasi aspirasi masyarakat dan siswa

3. Melaksanakan perubahan yang lebih kreatif dan inovatif dalam proses pembelajaran

4. Sebagai mitra Dinas Pendidikan dalam menyebarkan informasi kebijakan pendidikan

Arief Mangkoesaputro menjelaskan peranan MGMP sebagai:

1. Reformator dalam classroom reform terutama dalam reorientasi pembelajaran efektif

2. Mediator dalam pengembangan dan peningkatan kompetensi guru, terutama dalam pengembangan kurikulum dan sistem pengujian

3. Supporting agency dalam inovasi manajemen kelas dan manajemen sekolah

4. Collaborator terhadap unit terkait dan organisasi profesi yang relevan

5. Evaluator dan developer school reform dalam konteks MPMBS

6. Clinical and academic supervisor dengan pendekatan penilaian appraisal

Adapun fungsi MGMP adalah:

1. Menyusun program jangka panjang, jangka menengah, dan jangka pendek serta mengatur jadwal dan tempat kegiatan secara rutin

2. Memotivasi para guru untuk mengikuti kegiatan MGMP secara rutin, baik di tingkat sekolah, wilayah, maupun kota

3. Meningkatkan mutu kompetensi profesionalisme guru dalam perencanaan, pelaksanaan, dan pengujian/evaluasi pembelajaran di kelas, sehingga mampu mengupayakan peningkatan dan pemerataan mutu pendidikan di sekolah

4. Mengembangkan program layanan supervisi akademik klinis yang berkaitan dengan pembelajaran yang efektif

5. Mengembangkan silabus dan melakukan Analisis Materi Pelajaran (AMP), Program Tahunan (Prota), Program Semester (Prosem), Silabus dan Rencana Pelaksanaan Pembelajaran 
6. Mengupayakan lokakarya, simposium dan sejenisnya atas dasar inovasi manajemen kelas, manajemen pembelajaran efektif (seperti : PAKEM-Pendekatan Aktif, Kreatif, Efektif, dan Menyenangkan-, joyful and quantum learning, hasil classroom action research, hasil studi komparasi atau berbagai studi informasi dari berbagai nara sumber, dan lain-lain.)

7. Merumuskan model pembelajaran yang variatif dan alat-alat peraga praktik pembelajaran program Life Skill, baik Broad Based Education (BBE) maupun High Based Education (HBE)

8. Berpartisipasi aktif dalam kegiatan MGMP Propinsi dan AGMP nasional serta berkolaborasi dengan MKKS dan sejenisnya secara kooperatif

9. Melaporkan hasil kegiatan MGMP secara rutin setiap semester kepada Dinas Pendidikan Kabupaten/Kota

10. Memprakarsai pembentukan Asosiasi Guru Mata Pelajaran (AGMP) dan menyusun AD/ART MGMP Kabupaten/Kota (Arief Mangkusaputro, 2004: diakses dari Homepageartikel Pendidikan Network tanggal 17 Pebruari 2010).

Prinsip MGMP menurut Depdiknas (2004) adalah merupakan organisasi yang mandiri, dinamika organisasi yang dinamis berlangsung secara alamiah sesuai kondisi dan kebutuhan, mempunyai visi dan misi dalam upaya menembangkan pelayanan pendidikan khususnya proses pembelajaran yang efektif dan efisien,kreatif dan inovatif dalam mengembangkan ide-ide pembelajaran yang efektif dan efisien, memiliki Anggaran Dasar/anggaran Rumah Tangga (sekurang-kurangnya memuat nama dan tempat, dasar, tujuan dn kegiatan).

Kegiatan atau program kerja MGMP berdasar pedoman meliputi:

1. Meningkatkan Pemahaman Kurikulum.

Kegiatan MGMP dilaksanakan dalam rangka meningkatkan pemahaman guru tentang kurikulum yang digunakan dalam proses pembelajaran beserta perangkat pembelajaran yang dibutuhkan dalam mengajar sesuai dengan tuntutan kurikulum. Stelah mengikuti kegiatan MGMP guru diharapkan dapat membuat perangkat pembelajaran dan melaksanakan kurikulum dengan benar.

2. Mengembangkan Silabus dan Sistem Penilaian

Guru dituntut untuk mampu menyusun silabus, menentukan metode pembelajaran serta alat evaluasinya sesuai dengan materi dan karakteristik siswa.

3. Mengembangkan dan Merancang Bahan Ajar Guru dituntut untuk mampu mengembangkan bahan ajar pokok sehingga diharapkan akan dapat menyusun raancangan bahan pelajaran.

4. Meningkatkan Pemahaman tentang pendidikan Berbasis Luas dan Berorientasi Kecakapan Hidup 
Guru tidak hanya berfokus pada materi dalam mengajar tetapi juga bagaimana mengembangkan keterampilan siswa.

5. Mengembangkan Model Pembelajaran Inovatif

Pembelajaran dilaksanakan untuk mencapai tujuan secara optimal sehingga perlu diterapkan model pembelajaran yang inovatif.

6. Mengembangkan dan Melaksanakan Analisis Sarana Pembelajaran

Guru mampu merencanakan sarana pembelajaran yang tepat untuk mencapai tujuan pembelajaran.

7. Mengembangkan dan Membuat Alat Pembelajaran Sederhana

Guru dapat membuat alat pelajaran sesuai materi dan kemampuan sekolah untuk mencapai tujuan pembelajaran.

8. Mengembangkan dan Melaksanakan Program Pembelajaran

Berbasis Komputer

Guru dapat menerapkan sistem komputer dalam melaksanakan pembelajarannya

9. Mengembangkan Media dalam Melaksanakan Proses Belajar Mengajar.

Guru mampu merencanakan dan mengembangkan media yang cocok untuk gunakan dalam pencapaian tujuan pembelajaran.

MGMP dengan demikian mempunyai peran yang sangat penting dalam meningkatkan profesionalitas guru dalam melaksanakan pembelajaran. Untuk itu pemberdayaan MGMP sebagai sebuah wadah profesionalisme guru harus segera dilakukan. MGMP sebagai wadah peningkatan profesionalisme guru akan menjadi salah satu barometer keberhasilan pendidikan.

MGMP Akuntansi merupakan wadah profesional bagi guru-guru akuntansi SMK Program Keahlian Akuntansi untuk mengembangkan diri dan meningkatkan profesionalitasnya sebagai agen pembelajaran akuntansi. MGMP Akuntansi memberi ruang pada guru untuk berdiskusi memecahkan berbagai permasalahan pembelajaran baik dalam memahami isi kurikulum, menjabarkan dan mengkaji kurikulum serta melaksanakan kurikulum. MGMP sebagai forum komunikasi dipandang mampu untuk memenuhi kebutuhan guru dalam mengembangkan diri dan meningkatkan profesionalitasnya untuk meningkatkan kualitas pendidikan.

Guru menurut Undang Undang No. 14 tahun 2005 merupakan pendidik profesional dengan tugas utama mendidik, mengajar, membimbing, mengarahkan, melatih, menilai, dan mengevaluasi peserta didik pada pendidikan anak usia dini jalur formal, pendidikan dasar, dan pendidikan menengah. Guru dituntut untuk mempunyai profesionalitas dalam menjalankan tugasnya. Profesionalitas guru dibuktikan dengan dimilikinya sertifikat pendidik. Profesionalitas guru dimaksudkan untuk meningkatkan martabat dan peran guru sebagai agen pembelajaran yang berfungsi untuk meningkatkan mutu pendidikan nasional. 
Hasan (2009) mengemukakan guru Indonesia yang profesional dipersyaratkan mempunyai; (1) dasar ilmu yang kuat sebagai pengejawantahan terhadap masyarakat teknologi dan masyarakat ilmu pengetahuan di abad 21; (2) penguasaan kiat-kiat profesi berdasarkan riset dan praksis pendidikan yaitu ilmu pendidikan sebagai ilmu praksis bukan hanya merupakan konsepkonsep belaka. Pendidikan merupakan proses yang terjadi di lapangan dan bersifat ilmiah, serta riset pendidikan hendaknya diarahkan pada praksis pendidikan masyarakat Indonesia; (3) pengembangan kemampuan profesional berkesinambungan, profesi guru merupakan profesi yang berkembang terus menerus dan berkesinambungan antara LPTK dengan praktek pendidikan. Kekerdilan profesi guru dan ilmu pendidikan disebabkan terputusnya program pre-service dan in-service karena pertimbangan birokratis yang kaku atau manajemen pendidikan yang lemah

Guru profesional memiliki lima kuafikasi (1) akademik, (2) kompetensi, (c) sertifikat, (d) kesehatan lahir dan batin, dan (e) merealisasikan tujuan pendidikan (Joni, 2008a). Secara khusus Joni (2008b) menyebut The Four Pillars of Learning yang lepas-konteks itu menjadi (a) kompetensi pedagogik, (b) kompetensi kepribadian, (c) kompetensi profesional, dan (d) kompetensi sosial.

Kompetensi pedagogik berkaitan dengan kemampuan guru untuk melaksanakan pembelajaran. Kompetensi kepribadian berkaitan dengan kemampuan guru untuk menjadi teladan yang dewasa, arif dan bijaksana. Kompetensi profesional atau kompetensi akademik berkaitan dengan kemampuan guru dalam menguasai materi/bidang studi yang diajarkan, sedang kompetensi sosial berkaitan dengan kemampuan guru untuk berkomunikasi dan menggunakan teknologi informasi dan komunikasi dalam mengkomunikasikan bahan pelajaran.

Guru profesional akan dapat menyelenggarakan proses belajar mengajar yang menyenangkan, sehingga dapat mendorong kreativitas pada diri siswa. Guru profesional dituntut memiliki kode etik, yaitu norma tertentu sebagai pegangan yang diakui serta dihargai oleh masyarakat. Kode etik merupakan landasan moral dan pedoman tingkah laku yang dijunjung tinggi oleh sikap anggotanya. Guru memiliki otonomi khusus dapat mengatur diri sendiri, memiliki sikap mandiri dalam melaksanakan tugas. Guru membuat keputusan dan dapat mempertanggungjawabkan keputusan tersebut (Jatmiko, 2008)

Profesionalitas guru dapat dilihat dari berbagai aspek yakni:

1. peningkatan kualitas pembelajaran dengan memberdayakan berbagai aspek sehingga guru meningkat kreativitas dan produktivitasnya. Kreativitas dan produktivitas menjangkau berbagai aspek pendukung pembelajaran dari persiapan, pelaksanaaan pembelajaran, metode, media, evaluasi, dan tindak lanjut. 
2. penguasaan, penerapan, dan produk ilmu pengetahuan dan teknologi, seperti menulis buku, karya ilmiah, penelitian, membuat alat peraga, penerapan aspek teknologi dalam pembelajaran seperti media baik yang dihasilkan dalam bentuk software maupun hardware. Dengan cara demikian, dapat dikembangkan unit produksi yang memberikan kontribusi pada sekolah, mengembangkan jiwa kewirausahaan, kerjasama, dan sebagainya.

3. kontribusi guru dalam karya yang dapat dimanfaatkan orang lain juga dapat dijadikan tolok ukur profesionalitas guru. Guru-guru dapat menyebarluaskan temuannya ke berbagai media sehingga para stakeholder dapat turut merunut dan memanfaatkan karya guru.

4. penerapan strategi atau teknologi baru dalam pembelajaran seperti e-learning, lesson study, quantum learning, konstruktivisme

5. memanfaatkan teknologi informasi sebagai sarana pembelajaran sepert internet.

6. motivasi terus berkembang untuk maju dan berkualitas dalam pembelajaran, administrasi, pengembangan diri, yang mengarah pada perbaikan dan peningkatan kualitas pembelajaran.

Profesionalitas guru dijaga dan ditingkatkan dengan komitmennya untuk terus dan terus belajar, tanpa itu maka guru akan kerdil dalam ilmu pengetahuan, akan tetap tertinggal oleh akselerasi zaman yang semakin tidak menentu. Apalagi pada kondisi kini kita dihadapkan pada era global, semua serba cepat, serba dinamis, dan serba kompetitif, sehingga guru harus terus menyesuaikan dengan tuntutan zaman.

\section{B. Metode Penelitian}

Penelitian ini merupakan penelitian deskriptif untuk memperoleh gambaran program kerja dan peran MGMP Akuntansi DIY dalam meningkatan profesionalitas guru Akuntansi SMK. Subjek penelitian adalah pengurus dan anggota MGMP Akuntansi DIY yang berasal dari 51 sekolah SMK di DIY yang memiliki Program Keahlian Akuntansi. Pengurus dan anggota MGMP Akuntansi adalah guru akuntansi SMK yang mempunyai Program Keahlian Akuntansi se Daerah Istimewa Yogyakarta.

Data dikumpulkan melalui tiga teknik yaitu melalui teknik angket, wawancara dan dokumentasi sebagai triangulasi untuk memastikan kesahihan data. Instrumen penelitian berupa angket untuk memperoleh data peran MGMP dalam meningkatkan profesionalitas guru dengan responden anggota MGMP Akuntansi, pedoman wawancara untuk memperoleh data program kerja, kendala dan usaha yang telah dilakukan MGMP Akuntansi dan dokumentasi untuk memperoleh data program kerja MGMP Akuntansi. 
Teknik analisis data yang digunakan adalah analisis deskriptif untuk menggambarkan program kerja MGMP Akuntansi, peran, kendala dan usaha yang telah dilakukan untuk mengatasi kendala dalam menjalankan program kerja MGMP Akuntansi untuk meningkatkan profesionalitas guru Akuntansi SMK. Data hasil wawancar dideskripsikan dengan memaparkan dan mengambil kesimpulan sedag data yang dikumpulkan dengan angket dianalisis untuk dideskripsikan berdasarkan mean, simpangan baku, dan kategorisasi. Data disajikan dalam bentuk tabel dan gambar berdasarkan persentase. Penyajian data dalam bentuk persentase selanjutnya dideskripsikan dan diambil kesimpulan berdasarkan kriteria. Untuk mengetahui tingkat kecenderungan masing-masing komponen dilakukan dengan mengkategorisasi tingkat kecenderungan. Untuk itu diperlukan mean ideal dan simpangan baku/standar deviasi (SD) ideal, skor tertinggi dan skor terendah yang diperoleh instrumen sebagai kriterianya. Tingkat kecenderungan dibagi empat kategori dengan jarak 1,5 SD (ideal). Penentuan jarak 1,5 SD didasari asumsi distribusi populasi normal dengan 6 SD. Tingkat kecenderungan tersebut dijadikan sebagai kriteria peran MGMP dalam meningkatkan profesionalitas guru.

\section{Hasil Penelitian dan Pembahasan}

1. Hasil penelitian

Data mengenai peran MGMP dalam meningkatkan profesionalitas guru Akuntansi diperoleh melalui teknik kuesioner yang diberikan pada 38 Sekolah Menengah Kejuruan Kelompok Bisnis dan Manajemen Program Keahlian Akuntansi DIY, sedang data yang diperoleh dengan teknik wawancara diperoleh dari pengurus MGMP Akuntansi DIY. Penelitian yang dilakukan dengan menggunakan instrumen kuisioner, wawancara memperoleh hasil sebagai berikut:

a. Program kerja MGMP Akuntansi Kelompok Bisnis dan Manajemen DIY

Program kerja MGMP Akuntansi disusun untuk setiap tahun sekali. Penyusunan dilakukan oleh pengurus atas dasar kebutuhan dan masukan dari para anggotanya. Kegiatan - kegiatan yang diagendakan diantaranya adalah kegiatan yang berkaitan dengan peningkatan profesionalitas guru. Kegiatan ini rutin diadakan dalam empat tahun terakhir. Peningkatan proesionalisme guru merupakan kegiatan yang dilaksanakan melalui kerjasama MGMP Akuntansi dengan lembaga pendidikan yang ada di Yogyakarta diantaranya adalah UNY.

Program selain kegiatan peningkatan profesionlitas guru adalah pembahasan mengenai kurikulum terutama kalau ada peraturan yang baru sehingga persepsi di antara guru menjadi sama. Kegiatan serupa adalah penyusunan silabus dan rencana pelaksanaan pembelajarn dan pelaksanaan uji kompetensi produktif bagipeserta didik. Selain itu pembahasan dan evaluasi pelaksanaan LKS juga menjadi agenda MGMP. Hal ini sesuai dengan penuturan dari Bapak Rmn yang menyatakan bahwa" 
program MGMP rutin direncanakan dan dilaksanakan tiap tahun, ada peningkatan kemampuan guru, pelatihan dan pembahasan kurikulum serta LKS"

Evaluasi program kerja dilaksanakan setiap akhir tahun. Evaluasi dimaksudkan untuk melihat ketercapain, kendala, maupun hal-hal yang belum dicapai dalam tahun berjalan.

b. Peran MGMP Akuntansi Kelompok Bisnis dan Manajemen DIY dalam meningkatkan profesionalitas guru Akuntansi SMK di DIY Data mengenai peran MGMP dalam meningkatkan profesionalitas guru diperoleh melalui teknik kuisioner. Berdasarkan hasil yang diperoleh gambaran sebagai berikut:

1) Reformasi Pembelajaran

Hasil penelitian menunjukkan bahwa skor tertinggi yang diperoleh adalah sebesar 72 sama dengan skor tertinggi yang mungkin dapat dicapai. Sedangkan skor terendah yang dicapai adalah 46 dari skor terendah yang mungkin dapat dicapai sebesar 18. Mean yang dicapai adalah 56,18 median sebesar 55 dan modus sebesar 54.

Tabel 2. Kecenderungan Peran MGMP Akuntansi dalam Reformasi Pembelajaran

\begin{tabular}{|c|l|l|c|c|}
\hline NO & \multicolumn{1}{|c|}{ Kategori } & \multicolumn{1}{|c|}{ Rentang } & Jumlah & Persentase \\
\hline 1 & Sangat Tinggi & $>58,5$ & 10 & 26,3 \\
\hline 2 & Tinggi & $45<\mathrm{X} \leq 58,5$ & 28 & 73,7 \\
\hline 3 & Rendah & $31,5<\mathrm{X} \leq 45$ & 0 & 0 \\
\hline 4 & Sangat Rendah & $\leq 31,5$ & 0 & 0 \\
\hline Jumlah & & & 38 & 100 \\
\hline
\end{tabular}

Berdasarkan tabel 2 dapat diketahui bahwa peran MGMP Akuntansi dalam reformasi pembelajaran mempunyai kecenderungan sangat tinggi $26,3 \%$, tinggi $73,7 \%$ dan tidak ada yang tergolong rendah maupun sangat rendah.

2) Mediator peningkatan kompetensi guru

Hasil penelitian menunjukkan bahwa skor tertinggi yang diperoleh adalah sebesar 36 sama dengan skor tertinggi yang mungkin dapat dicapai. Sedangkan skor terendah yang dicapai adalah 9 sama dengan skor terendah yang mungkin dapat dicapai. Mean yang dicapai adalah 28,58 median sebesar 28,5 dan modus sebesar 27.

Tabel 3. Kecenderungan Peran MGMP sebagai Mediator Peningkatan Kompetensi Guru

\begin{tabular}{|c|l|l|c|c|}
\hline NO & \multicolumn{1}{|c|}{ Kategori } & \multicolumn{1}{c|}{ Rentang } & Jumlah & Persentase \\
\hline 1 & Sangat Tinggi & $>29,25$ & 14 & 36,8 \\
\hline 2 & Tinggi & $22,5<\mathrm{X} \leq 29,25$ & 22 & 57,9 \\
\hline 3 & Rendah & $15,75<\mathrm{X} \leq 22,5$ & 2 & 5,3 \\
\hline 4 & Sangat Rendah & $\leq 15,75$ & 0 & 0 \\
\hline Jumlah & & & 38 & 100 \\
\hline
\end{tabular}


Tabel 3 menunjukkan bahwa kecenderungan peran MGMP Akuntansi sebagai mediator peningkatan kompetensi guru sangat tinggi sebesar 36,8\%, peran MGMP Akuntansi sebagai mediator peningkatan kompetensi guru tergolong tingggi sebesar 57,9\%, sedang peran MGMP Akuntansi sebagai mediator peningkatan kompetensi guru yang tergolong rendah adalah sebesar 5,3\% dan tidak ada peran MGMP Akuntansi dalam peningkatan kompetensi guru yang tergolong rendah.

3) Supporting Agency dalam Inovasi Manajemen Kelas dan Sekolah

Hasil penelitian menunjukkan bahwa skor tertinggi yang diperoleh adalah sebesar 24 sama dengan skor tertinggi yang mungkin dapat dicapai. Sedangkan skor terendah yang dicapai adalah 6 sama dengan skor terendah yang mungkin dapat dicapai. Mean yang dicapai adalah 18 median sebesar 18 dan modus sebesar 18 .

Tabel 4. Kecenderungan Peran MGMP Akuntansi sebagai Supporting Agency dalam Inovasi Manajeman Kelas dan Sekolah

\begin{tabular}{|c|l|l|c|c|}
\hline NO & \multicolumn{1}{|c|}{ Kategori } & \multicolumn{1}{c|}{ Rentang } & Jumlah & Persentase \\
\hline 1 & Sangat Tinggi & $>19,5$ & 10 & 26,3 \\
\hline 2 & Tinggi & $15<\mathrm{X} \leq 19,5$ & 22 & 57,9 \\
\hline 3 & Rendah & $10,5<\mathrm{X} \leq 15$ & 5 & 13,2 \\
\hline 4 & Sangat Rendah & $\leq 10,5$ & 1 & 2,6 \\
\hline Jumlah & & & 38 & 100 \\
\hline
\end{tabular}

Tabel di atas menunjukkan bahwa kecenderungan peran MGMP Akuntansi sebagai suporting agency dalam inovasi manajemen kelas dan sekolah sangat tinggi sebesar 26,3\%, sangat tinggi $57,9 \%$, rendah $13,2 \%$ dan sangat rendah $2,6 \%$.

4) Collaborator Sekolah

Hasil penelitian menunjukkan bahwa skor tertinggi yang diperoleh adalah sebesar 40 dari skor tertinggi yang mungkin dapat dicapai sebesar 50. Sedangkan skor terendah yang dicapai adalah 18 dari skor terendah yang mungkin dapat dicapai yaitu sebesar 10. Mean yang dicapai adalah 31,66 median sebesar 30,5 dan modus sebesar 30 .

Tabel 5. Kecenderungan Peran MGMP Akuntansi sebagai Collaborator Sekolah

\begin{tabular}{|c|l|l|c|c|}
\hline NO & \multicolumn{1}{|c|}{ Kategori } & \multicolumn{1}{c|}{ Rentang } & Jumlah & Persentase \\
\hline 1 & Sangat Tinggi & $>32,5$ & 15 & 39,5 \\
\hline 2 & Tinggi & $25<\mathrm{X} \leq 32,5$ & 22 & 57,9 \\
\hline 3 & Rendah & $17,5<\mathrm{X} \leq 25$ & 1 & 2,6 \\
\hline 4 & Sangat Rendah & $\leq 17,5$ & 0 & 0 \\
\hline Jumlah & & & 38 & 100 \\
\hline
\end{tabular}


Tabel 5 menunjukkan bahwa peran MGMP Akuntansi sebagai collaborator sekolah sangat tinggi sebesar 39,5\%, tinggi sebesar $57,9 \%$, rendah sebesar $2,6 \%$ dan tidak ada peran MGMP Akuntansi sebagai collaborator sekolah yang tergolong rendah

5) Evaluator Sekolah

Hasil penelitian menunjukkan bahwa skor tertinggi yang diperoleh adalah sebesar 39 dari skor tertinggi yang mungkin dapat dicapai sebesar 40. Sedangkan skor terendah yang dicapai adalah 18 sama dengan skor terendah yang mungkin dapat dicapai. Mean yang dicapai adalah 29,1 median sebesar 30 dan modus sebesar 30 .

Tabel 6. Kecenderungan Peran MGMP sebagai Evaluator Sekolah

\begin{tabular}{|c|l|l|c|c|}
\hline NO & \multicolumn{1}{|c|}{ Kategori } & \multicolumn{1}{c|}{ Rentang } & Jumlah & Persentase \\
\hline 1 & Sangat Tinggi & $>32,5$ & 6 & 15,8 \\
\hline 2 & Tinggi & $25<\mathrm{X} \leq 32,5$ & 26 & 68,4 \\
\hline 3 & Rendah & $17,5<\mathrm{X} \leq 25$ & 5 & 13,2 \\
\hline 4 & Sangat Rendah & $\leq 17,5$ & 1 & 2,6 \\
\hline Jumlah & & & 38 & 100 \\
\hline
\end{tabular}

Tabel 6 menunjukkan bahwa kecenderungan peran MGMP Akuntansi sebagai evaluator sekolah sangat tinggi sebesar $15,8 \%$ dan tinggi sebesar $68,4 \%$. Kecenderungan peran MGMP Akuntansi sebagai evaluator sekolah tergolong rendah sebesar 13,2\% dan sangat rendah sebesar 2,6\%.

6) Supervisi Akademik dan Klinis

Hasil penelitian menunjukkan bahwa skor tertinggi yang diperoleh adalah sebesar 20 sama dengan skor tertinggi yang mungkin dapat dicapai. Sedangkan skor terendah yang dicapai adalah 5 sama dengan skor terendah yang mungkin dapat dicapai. Mean yang dicapai adalah 14,53 median sebesar 15 dan modus sebesar 15 .

Tabel 7. Kecenderungan Peran MGMP dalam Supervisi Akademik dan Klinis

\begin{tabular}{|c|l|l|c|c|}
\hline NO & \multicolumn{1}{|c|}{ Kategori } & \multicolumn{1}{c|}{ Rentang } & Jumlah & Persentase \\
\hline 1 & Sangat Tinggi & $>16,25$ & 4 & 10,5 \\
\hline 2 & Tinggi & $12,5<\mathrm{X} \leq 16,25$ & 28 & 73,7 \\
\hline 3 & Rendah & $17,5<\mathrm{X} \leq 12,5$ & 5 & 13,2 \\
\hline 4 & Sangat Rendah & $\leq 8,75$ & 1 & 2,6 \\
\hline Jumlah & & & 38 & 100 \\
\hline
\end{tabular}

Tabel 7 menunjukkan bahwa kecenderungan peran MGMP dalam supervisi akademik dan supervisi klinis tergolong sangat tinggi sebesar 10,5\%, dan sangat tinggi sebesar $73,7 \%$. Kecenderungan peran MGMP Akuntansi dalam 
supervisi akademik dan supervisi klinis tergolong rendah sebesar 13,2 \% dan peran MGMP dalam supervisi akademik dan supervisi klinis yang tergolong sangat rendah sebesar $2,6 \%$.

c. Kendala yang dihadapi MGMP Akuntansi Kelompok Bisnis dan Manajemen DIY dalam menjalankan program kerjanya Kendala yang dihadapi dalam pelaksanaan program keja MGMP pada dasarnya bukan merupakan satu hal yang serius dan mengkhawatirkan. Menurut pengurus MGMP kendala yang dihadapai adalah factor pendanaan dan pengelolaan waktu. Pengelolaan waktu yang menjadi kendala adalah mengenai penjadwalan untuk pelaksanaan program. Hal ini dirasakan sulit bagi pengurus untuk menyelenggarakan program dengan peserta adalah guru akuntansi dari berbaai sekolah yang mempnyai jadwal mengajar yang tentu saja sangat beragam. Mencari waktu luang bagi kebanyakan guru adalah suatu hal yang tidak mudah.

Faktor lain yang menjadi kendala adalah pendanaan. Dana untuk keberlangsungan program tidak didapat dengan mudah oleh MGMP. Bantuan dana dari pemerintah tidak cukup menutup semua pengeluaran yang diakibatkan penyelenggaraan program kerja tersebut.

d. Usaha yang telah dilakukan MGMP Akuntansi Kelompok Bisnis dan Manajemen DIY untuk mengatasi kendala yang dihadapi

Sejauh ini usaha yang telah dilakukan oleh MGMP untuk mengatasi kendala waktu adalah dengan menyelenggarakan kegiatan pada waktu liburan/pergantian antar tahun. Akibatnya jika ada beberapa kegiatan bagi guru, maka akan menumpuk pada satu blok waktu tertentu saja. Hal ini dapat menyebabkan timbulnya kejenuhan akibat padatnya kegiatan. Dana yang menjadi kendala dapat diatasi dengan bantuan iuran dari sekolah yang mengirimkan anggota untuk kegiatan yang menjadi program kerja MGMP. Sejauh ini kegiatan dapat berjalan lancar.

2. Pembahasan

Program kerja MGMP disusun setiap 1 tahun sekali. Hal ini sudah sesuai dengan yang seharusnya. Program kerja MGMP tidak banyak akan tetapi dipilih kegiatan yang akan dapat meningkatkan profesionalitas guru Akuntansi. Kegiatan yang dimaksud adalah seminar, pelatihan, workshop dan sejenisnya. Program kerja MGMP evaluasi setiap akhir tahun. Evaluasi dimaksudkan untuk melihat ketercapaian program kerja serta melihat apa yang belum dapat dicapai.

Peran MGMP dalam meningkatkan profesionalitas guru Akuntansi dapat dikategorikan dalam tingkat tinggi. Hal ini dapat dilihat dalam masing-masing indikator yaitu peran MGMP dalam 
melakukan reformasi pembelajaran termasuk dalam kategori tinggi sebesar 73,7\%. Peran MGMP sebagai mediator peningkatan kompeteensi guru termasuk dalam kategori tinggi sebesar 57,9\%. Peran MGMP sebagai supporting agency dalam inovasi manajemen kelas dan sekolah tergolong tinggi yaitu sebesar $57,9 \%$. Peran sebagai collaborator sekolah tergolong tinggi yaitu sebesar 57,9\%. Peran MGMP sebagai evaluator sekolah termasuk dalam kategori tinggi yaitu sebesar $68,4 \%$. Peran MGMP dalam supervisi akademik dan klinis tergolong tinggi sebesar $73,7 \%$.

Dapat dikatakan bahwa MGMP mempunyai peran yang tinggi dalam meningkatkan profesionalitas guru. MGMP mampu mewadahi aspirasi dan kebutuhan guru untuk bertindak profesional. Guru memperoleh tempat untuk tumbuh dan berkembang menjadi lebih profesional. MGMP dapat dijadikan tempat untuk saling berbagi pengetahuan dan keterampilan dalam rangka peningkatan profesionalitas guru.

Hambatan dan kendala yang dihadapi MGMP dalam melaksanakan program kerjanya meliputi hambatan masalah pendanaaan dan waktu pelaksanaan. Hambatan ini bukan merupakan kendala yang utama, hanya masalah teknis saja. Dengan demikian hampir dapat dikatakan bahwa program kerja dapat berjalan lancar tanpa ada kendala yang berarti. Hambatan pendanaan yang dihadapi oleh MGMP diatasi dengan membayar iuran bagi anggota MGMP serta bantuan dana dari LPMP jika ada proyek bersama. Masalah waktu diatasi dengan memanfaatkan waktu liburan sekolah untuk berkegiatan dalam meningkatkan profesionalitas.

\section{Kesimpulan dan Saran}

1. Kesimpulan

Berdasarkan hasil penelitian dan pembahasan dapat ditarik kesimpulan sebagai berikut:

a. Program kerja MGMP disusun setiap tahun dan diadakan evaluasi pada akhir tahun. Program kerja yang terlaksana adalah peningkatan kemampuan guru, pembahasan kurikulum dan pembahasan mengenai LKS.

b. Peran MGMP dalam meningkatkan profesionalitas guru tergolong tinggi dilihat dari indikator peran dalam reformasi pembelajaran tergolong tinggi $(73,7 \%)$, sebagai mediator peningkatan kompetensi guru tergolong tinggi (57,9\%), sebagai supporting agency dalam inovasi manajemen kelas dan sekolah tergolong tinggi yaitu sebesar 57,9\%, peran MGMP sebagai collaborator sekolah tergolong tinggi (57,9\%), sebagai evaluator sekolah tergolong tinggi $(68,4 \%)$, serta dalam supervisi akademik dan klinis tergolong tinggi yaitu sebesar $73,7 \%$. 
c. Kendala yang dihadapi oleh MGMP adalah mengenai pendanaan yang belum optimal dan pengaturan waktu untuk pelaksanaan program kerja yang relatif sulit.

d. Usaha yang dilakukan oleh MGMP untuk mengatasi kendala adalah dengan mengadakan iuran bagi guru-guru agar program kerja dapat terlaksana dan menggunakan waktu libur sekolah untuk melaksanakan agenda program kerja.

2. Saran

Saran yang dapat diberikan adalah bahwa MGMP hendaknya:

a. Meningkatkan kinerjanya dengan menjalin kerjasama dengan beberapa instansi untuk meningkatkan profesionalitas guru.

b. Menggalang dana secara rutin untuk kegiatan, bukan hanya iuran ketika akan mengadakan pertemuan.

c. Mengagendakan program dan meratakan penyebarannya dalam satu tahun, tidak dipadatkan pada waktu liburan sekolah saja untuk menghindari kejenuhan.

\section{E. Daftar Pustaka}

Arief Mangkoesaputro. 2004. Memberdayakan MGMP, Suatu Keniscayaan.Artikel: diakses dari Hompepage Pendidikan Network pada tanggal 17 Pebruari 2010

Depdiknas. 2004. Pedoman MGMP. Jakarta: Direktorat Pendoidikan Dasar dan Menengah

Hasan, Ani M. 2008. Pengembangan Profesionalisme Guru di Abad Pengetahuan dalam http://re-searchengines.com/amhasan.html.

Jatmiko, Wahyu. 2008. Pentingnya Profesional Seorang Guru dalam http://batampos. co.id. Opini/Opini/Pentingnya_Profesional_Seorang Guru_.html

Sawali Tuhusetya. 2009. Pemberdayaan MGMP dan Kegelisahan Guru. Artikel. Diakses dari Blog Jalan Mendaki pada tanggal 17 Pebruaru 2010

Raka Joni, T. 2008. Model Pendidikan Guru dan Pendidikan Dosen, PraJabatan. Makalah disampaikan pada KONASPI tanggal 5- 7 November 2008 di Denpasar.

UURI No. 30 Tahun 2003 Tentang Sistem Pendidikan Nasional

UURI No. 14 Tahun 2005 Tentang Guru dan Dosen 